\title{
Factors related to recurrence in surgical treatment of hydatid cyst
}

\author{
Kist hidatiğin cerrahi tedavisinde rekürrens ile ilişkili faktörler
}

\author{
Ayetullah Temiz ${ }^{1}$, Gürkan Öztürk ${ }^{2}$, Abdullah Kısaoğlu ${ }^{3}$, Ercan Korkut ${ }^{2}$, Erdem Karadeniz ${ }^{2}$
}

\begin{abstract}
Aim: Curative treatment of cyst hydatid is surgical or interventional. However, recurrence is a very important problem today. In our study, we aimed to identify factors affecting recurrence in the surgical treatment of hydatid cyst.

Methods: This study was carried out retrospectively, and the files of 228 patients operated due to hydatid cyst were examined and data were recorded. 72 patients who did not meet the inclusion criteria were excluded from the study. Our results and factors affecting recurrence were examined.

Results: The recurrence was observed in 14 patients (8.9\%). No relationship could be found between the recurrence and other factors such as the localization of the cyst, Gharbi classification, applied surgical technique, the contents of the cyst, treatment, and relationship between the cyst and bile tract, postoperative complications, the number and diameter of the cyst.

Conclusion: Prospectively planned and involving larger patient groups studies are needed for the determination of the factors affecting recurrence after surgery of liver hydatid cyst.

Key Words: Liver, hydatid cyst, surgery, recurrence
\end{abstract}

Öz

Amaç: Kist hidatiğin küratif tedavisi cerrahi veya girişimseldir. Bununla birlikte kist hidatik tedavisinde rekürrens çok önemli bir sorun olarak karşımıza çıkmaktadır. Biz çalışmamızda kliniğimizde hidatik kist nedeniyle opere edilen hastalarda rekürrensi ve rekürrense etki eden faktörleri belirlemeyi amaçladık.

Yöntemler: Retrospektif olan bu çalışmada, hidatik kist hastalığı nedeniyle cerrahi uygulanan 228 hasta dosyası incelenerek veriler kayıt altına alındı. Bu hastalardan çalışmaya dahil edilme kriterlerine uymayan 72 hasta çalışma dışı tutuldu. Sonuçlarımız incelenerek rekürrense etkili faktörler irdelendi.

Bulgular: Hastaların 14'ünde (\%8.9) rekürrens tespit edildi. Kistin lokalizasyonu, Gharbi sınıflandırması, uygulanan cerrahi teknik, kistin içeriği, safra yolu iştiraki ve tedavisi, postoperatif komplikasyonlar, kistin sayısı ve çapı ile nüks arasında bir iliş̧i tespit edilmedi.

Sonuç: Karaciğer kist hidatiğinde cerrahi sonrası nükse etkili faktörlerin tespiti hususunda ileriye dönük olarak planlanmış ve daha geniş hasta gruplarını içeren çalışmaların yapılmasına ihtiyaç vardır.

Anahtar Kelimeler: Karaciğer, kist hidatik, cerrahi, rekürrens.
1 Erzurum Regional Training and Research Hospital, Department of General Surgery, Erzurum, Turkey.

2 Atatürk University Faculty of Medicine, Department of General Surgery, Erzurum, Turkey.

Akdeniz University Faculty of Medicine, Department of General Surgery, Antalya, Turkey.

Ethics Committee Approval: The study wass approved by the local ethical authority.

Etik Kurul Onayı: Çalıșma lokal etik komite tarafindan onaylanmıştır.

Conflict of Interest: No conflict of interest was declared by the authors.

Çıkar Çatışması: Yazarlar çıkar çatışması

bildirmemişlerdir.

Financial Disclosure: The authors declared that this study has received no financial support.

Finansal Destek: Yazarlar bu çalışma için finansal destek almadıklarını beyan etmişlerdir.

Geliş Tarihi / Received: 19.06.2018

Kabul Tarihi / Accepted: 10.09.2018

Yayın Tarihi / Published: 30.11.2018

Sorumlu yazar / Corresponding author:

Ayetullah TEMiz

Adres/Address: Erzurum Bölge Eğitim ve Araștıma

Hastanesi, Genel Cerrahi Kliniği

Palandöken/Erzurum - Türkiye.

e-posta: temiz-49@hotmail.com

Tel/Phone: +90 5057507808

Copyright $\odot$ ACEM 


\section{Introduction}

Hydatid cyst, or echinococcosis, is a zoonotic disease seen in parts of the world where breeding sheep is common. This is an important health care issue in our country, especially in Eastern and Southeastern Anatolian Regions [1, 2]. Hydatid cyst of the liver is asymptomatic in 40-60\% of the patients and pain is the most common symptom when it is symptomatic. Other common findings of this disease are jaundice and fever [2].

Diagnosis has become easier with improvement of imaging techniques; however, effective medical treatment is not still available. Curative treatment of hydatid cyst is surgical or interventional. Recurrence is a major problem following the surgical treatment of hydatid cyst. Despite the fact that it is a benign disease, treatment of its complications and recurrences are very challenging issues.

Case series reported from Turkey which is an endemic country for the disease have shown that recurrence rate is 3.4-24 $\%$ varying with different surgical methods [3]. In literature, recurrence rate during 5-year follow-up is determined as from 0.9 to $11.3 \%[4,5]$.

We aimed to determine recurrence and factors affecting recurrence in patients who were operated in our clinic for hydatid cysts.

\section{Material and methods}

In this retrospective study, we examined medical records of 228 patients who were operated for hydatid cyst in our clinic between January 1999 and December 2008 after obtaining ethical committee approval. Content of this study was explained to all patients and informed consent forms were obtained. Data such as age, sex, complaints upon arrival, laboratory findings, and location of the cysts, diameter $(\mathrm{cm})$, number and type of the cysts according to Gharbi classification were recorded as in previous studies [6]. Whether preoperative endoscopic retrograde cholangiopancreatography (ERCP) is performed, surgical methods, contents of the cyst, whether the cyst is associated with bile ducts, preoperative and postoperative albendazole use, complications and treatment for these complications were also recorded.

Patients with missing data in files, who cannot be reached and patients who did not accept to participate in the study were excluded from the study.

Seventy two patients who did not meet study criteria were excluded. Patients with complete files were reached and invited for control examination. Therefore, a total of 156 patients were included in the study. Abdominal ultrasound (US) and computed tomography (CT) in suspicious cases were performed. If recurrence was suspected with radiological studies, serologic tests with Enzyme-Linked Immunosorbent Assay (ELISA) were ordered. Live cysts detected in radiological studies in location of the primary disease or in any other intraabdominal region after treatment for a primary disease, and any increase in levels of serological tests was considered as diagnostic criteria for recurrence. When recurrence was detected in the primary disease site, it was referred to as local recurrence, and when it was found away from the primary site, it was referred to as disseminated disease.

Surgical procedures included both radical and conservative surgery. Radical surgery involved pericystectomy or hepatectomy (segmentectomy and lobectomy). Parenchymal transection was performed using the clamping technique or by ultrasonic aspiration (Cavitron Ultrasound Surgical Aspirator, CUSA). Vascular and biliary structures were connected using sutures and clips. Drainage with omentoplasty or capitonnage was performed in case of conservative surgery. Hypertonic saline at a concentration of $30 \%$ was used as a scolicidal solution. When cyst fluid containing bile was detected in the puncture, no scolicidal agent was used. To prevent accidental spillage of the cystic contents, the puncture site was covered with hypertonic saline solution soaked in a gauze. Small bile leaks in the cyst cavity were repaired by a primer suture. $\mathrm{T}$ tube was applied as an additional treatment of the primer for very large leaks.

Albendazole (Andazol, $200 \mathrm{mg}$ oral tablet, Biofarma, Istanbul, Turkey) in a dose of $10 \mathrm{mg} / \mathrm{kg} /$ day was given twice daily for 15 days before the operation and 3 months after the operation as medical treatment.

In the follow-up period, an initial control abdominal ultrasound was routinely performed at the postoperative third month and the sixth month, followed by an annual examination.

\section{Statistical analysis}

Recorded data was analyzed with SPSS 15.0 for Windows Evaluation version (SPSS Inc., Chicago, IL, USA) by using T-test and chi square test; recurrence rates and factors affecting the recurrence were examined. Continuous variables are expressed as mean \pm standard derivations (SD) and categorical variables as frequencies (percentages). $\mathrm{p}$ values smaller than 0.05 were interpreted as statistically significant.

\section{Results}

One hundred and fifty six patients were included in this study. Fifty nine patients (38\%) were male and 97 patients $(62 \%)$ were female. There were 14 recurrent cases (8.9\%). Characteristic features of these 14 recurrence cases are shown in Table 1 and Table 2.

Complaints upon arrival were abdominal pain in all of the 156 patients, sensation of abdominal fullness in $23(14.7 \%)$ patients, jaundice and pruritus in 11 patients (7\%), acute abdominal findings in two patients $(1.2 \%)$. All recurrent cases presented with abdominal pain but did not have other complaints. There was no relation between the complaints and recurrence $(\mathrm{p}=0.292)$. Demographic and clinical findings of the patients with and without recurrence are given in Table 3. Mean age was $44 \pm 15.2$ years in patients with recurrence and was $39.94 \pm$ 17.55 years in patients without recurrence. There was no significant difference in demographic and clinical findings except the use of medical treatment between the patients with and without recurrence (Table 3). It was found that all patients with recurrence used both preoperative and postoperative albendazole treatment. However, for the patients without recurrence, it was detected that 115 patients $(80 \%)$ and 125 patients $(88 \%)$ used preoperative and postoperative medical treatment, respectively. However, the difference is not statistically significant $(\mathrm{p}=0.357)$.

Table 1: Characteristics of the patients with recurrence.

\begin{tabular}{lcccccc} 
No & $\begin{array}{c}\text { Sex } \\
(\mathrm{M} / \mathrm{F})\end{array}$ & $\begin{array}{c}\text { Age } \\
\text { (year) }\end{array}$ & $\begin{array}{c}\text { Preop } \\
\text { ERCP }\end{array}$ & Surgery & $\begin{array}{c}\text { Preop } \\
\text { Med. } \\
\text { Tx. }\end{array}$ & $\begin{array}{c}\text { Postop } \\
\text { Med. Tx. }\end{array}$ \\
\hline 1 & $\mathrm{~F}$ & 48 & - & $\mathrm{O}+\mathrm{T}$ & + & + \\
2 & $\mathrm{~F}$ & 55 & - & $\mathrm{T}$ & + & + \\
3 & $\mathrm{M}$ & 53 & - & $\mathrm{T}$ & + & + \\
4 & $\mathrm{~F}$ & 22 & - & $\mathrm{O}+\mathrm{T}$ & + & + \\
5 & $\mathrm{~F}$ & 47 & - & $\mathrm{T}$ & + & + \\
6 & $\mathrm{M}$ & 44 & - & $\mathrm{C}+\mathrm{T}$ & + & + \\
7 & $\mathrm{~F}$ & 33 & - & $\mathrm{O}+\mathrm{T}$ & + & + \\
8 & $\mathrm{~F}$ & 30 & - & $\mathrm{O}+\mathrm{T}$ & + & + \\
9 & $\mathrm{~F}$ & 40 & - & $\mathrm{O}+\mathrm{T}$ & + & + \\
10 & $\mathrm{M}$ & 80 & + & $\mathrm{O}+\mathrm{T}$ & + & + \\
11 & $\mathrm{M}$ & 51 & - & $\mathrm{O}+\mathrm{T}$ & + & + \\
12 & $\mathrm{~F}$ & 35 & - & $\mathrm{O}+\mathrm{T}$ & + & + \\
13 & $\mathrm{~F}$ & 55 & - & $\mathrm{O}+\mathrm{T}$ & + & + \\
14 & $\mathrm{~F}$ & 23 & - & $\mathrm{O}+\mathrm{T}$ & + & + \\
\hline
\end{tabular}


M: male, F: female, ERCP: endoscopic retrograde cholangiopancreatography, O: omentoplasty, $\mathrm{T}$ : tube drainage, $\mathrm{C}$ : capitonnage.

Table 2: Characteristics of the cysts of the patients with recurrence.

\begin{tabular}{|c|c|c|c|c|c|c|c|}
\hline No & $\begin{array}{l}\text { Localiza } \\
\text { tion }^{*}\end{array}$ & $\begin{array}{l}\text { Cyst } \\
\text { (n) }\end{array}$ & $\begin{array}{l}\text { Diam } \\
\text { eter } \\
(\mathrm{cm})\end{array}$ & $\begin{array}{l}\text { Gharbi } \\
\text { grade }\end{array}$ & Content & $\begin{array}{l}\text { Biliary } \\
\text { spillage }\end{array}$ & $\begin{array}{l}\text { Biliary } \\
\text { fistula }\end{array}$ \\
\hline 1 & $\begin{array}{l}\text { Liver } \\
(6-8)\end{array}$ & 1 & 15 & 2 & $\begin{array}{l}\text { Rock } \\
\text { water }\end{array}$ & - & - \\
\hline 2 & Pelvis & 1 & 10 & 3 & $\begin{array}{l}\text { Rock } \\
\text { water }\end{array}$ & - & - \\
\hline 3 & $\begin{array}{c}\text { Liver } \\
(6-7)\end{array}$ & 1 & 10 & 3 & Purulent & - & - \\
\hline 4 & $\begin{array}{l}\text { Liver } \\
(7-8)\end{array}$ & 1 & 10 & 3 & $\begin{array}{l}\text { Rock } \\
\text { water }\end{array}$ & - & - \\
\hline 5 & $\begin{array}{l}\text { Liver } \\
(7)\end{array}$ & 1 & 10 & 3 & $\begin{array}{l}\text { Rock } \\
\text { water }\end{array}$ & - & - \\
\hline 6 & $\begin{array}{l}\text { Liver } \\
(8)- \\
\text { uterus }\end{array}$ & 2 & 10 & 4 & $\begin{array}{l}\text { Rock } \\
\text { water }\end{array}$ & - & - \\
\hline 7 & $\begin{array}{l}\text { Liver } \\
(6-7)\end{array}$ & 1 & 10 & 4 & $\begin{array}{l}\text { Rock } \\
\text { water }\end{array}$ & - & - \\
\hline 8 & $\begin{array}{c}\text { Liver } \\
\text { (7)- } \\
\text { pancreas }\end{array}$ & 2 & 10 & 4 & $\begin{array}{l}\text { Rock } \\
\text { water }\end{array}$ & - & - \\
\hline 9 & $\begin{array}{l}\text { Liver } \\
(6-7)\end{array}$ & 1 & 10 & 3 & Purulent & - & - \\
\hline 10 & $\begin{array}{l}\text { Liver } \\
(6-8)\end{array}$ & 4 & 15 & 3 & Bile & + & + \\
\hline 11 & $\begin{array}{l}\text { Liver } \\
(4-6)\end{array}$ & 2 & 15 & 3 & $\begin{array}{l}\text { Rock } \\
\text { water }\end{array}$ & - & - \\
\hline 12 & $\begin{array}{l}\text { Liver } \\
(7-8)\end{array}$ & 1 & 10 & 3 & $\begin{array}{l}\text { Rock } \\
\text { water }\end{array}$ & - & - \\
\hline 13 & $\begin{array}{l}\text { Liver } \\
(7-8)\end{array}$ & 1 & 5 & 4 & $\begin{array}{l}\text { Rock } \\
\text { water }\end{array}$ & - & - \\
\hline 14 & $\begin{array}{l}\text { Liver } \\
(8)\end{array}$ & 1 & 13 & 4 & $\begin{array}{l}\text { Rock } \\
\text { water }\end{array}$ & - & - \\
\hline
\end{tabular}

${ }^{¥}$ : Numbers in parenthesis showing number of the segment/segments of the liver.

\section{Discussion}

Different recurrence rates of hydatid cyst disease have been reported in different series. The recurrence rate during a 5year follow-up period has been reported to be $0.9 \%-11.3 \%$ in the literature $[3,4]$. Recurrence rate can differ in the same study center at different time points. Secchi et al. [4] had reported a recurrence rate of $7.2 \%$ in the early postoperative stage of conservative surgery before 1990 , whereas this rate was found to decrease to $1.6 \%$ for the same type of surgery after 1990. Advancements in techniques and experience could have played a major role in this decrease. Our rate was consistent with the literature.

It is suggested that follow-up of the operated patients every 6 months by performing an annual abdominal ultrasound examination for at least 3 years is essential because most recurrences have been observed in this time period as in the present study [7].

There are no prospective studies determining the reasons for recurrence in hydatid cyst disease. However, some important aspects have been emphasized in relation to recurrence. The primary reasons that have been emphasized in the literature [8-10] are as follows:

a) Spillage of cyst contents into the intraperitoneal area during discharge of cyst,

b) Improper use of scolicidal agents,

c) Undiagnosed cysts before and after surgery,

d) Failure to remove all live cyst contents during the first surgery,

e) Failure to reach pockets in the pericyst during the conservative approach,

f) Direct rupture of the cyst into the liver.

Maliki et al. [11] stated that cysts localized in central segments have statistically significantly higher recurrence rates than those localized in lateral segments. However, two studies from our country could not find any statistically significant effect of cyst localization on recurrence [12]. We also did not find any significant relationship between cyst localization and recurrence. The literature states that there is no relationship between Gharbi classification and recurrence [11,12]. Similarly, in our study, despite the fact that the cysts were primarily of Gharbi classification type 3 , there was no relationship with recurrence.

In the literature, it has been reported that the size and number of cysts have an effect on recurrence. A study involving 672 patients reported that when there are three or more cysts, the recurrence rate increases by 3.8 times. The same study demonstrated that the recurrence rate is higher in cysts measuring $10 \mathrm{~cm}$ or larger than in cysts measuring smaller than $10 \mathrm{~cm}$ and this difference was found to be statistically significant in the single variant analysis [11]. Nonetheless, there are studies that report that cyst size and number have no impact on recurrence rate [12]. Similarly, in this study, we determined that cyst size and number do not have any effect on recurrence.

The World Health Organization (WHO) reports that preoperative medical treatment with albendazole decreases recurrence and facilitates surgery by reducing the pressure inside the cyst, thus recommending the use of albendazole $[13,14]$. In a study conducted by Arif et al. [15], the recurrence rate in patients who did not use albendazole was $18.5 \%$, whereas it was $4.16 \%$ in patients who used albendazole. However, in our study, all patients with recurrence used albendazole in both the preoperative and postoperative periods, but among those patients who did not have recurrence, $115(80 \%)$ patients used it preoperatively and 125 (88 \%) used it postoperatively. However, the variety of albendazole use has not reached a statistically significant level among the groups.

One of the major reasons for recurrences, primarily local recurrences, is insufficient or inappropriate surgical technique. Local recurrence risk is lower in radical surgical interventions such as pericystectomy and liver resection, because these methods clear the cyst completely without any remains. It has been argued in the literature that with methods that leave some or all of the pericystic tissue, the recurrence rates will be higher [16]. This is based on the view that live scolex can remain in the pericystic tissue.

On the other hand, there are studies showing that scolexes are not found in the pericystic tissue histologically [9]. Thus, the view that defends recurrences occurs because the remaining tissue is weakened. A general idea is that recurrence rates with radical surgery are lower than the rates with conservative surgery. A study from our country stated that recurrence rates with conservative surgery performed by experienced surgeons decreased from $20 \%$ to $5 \%$ [17]. Secchi et al. [4] reported that the recurrence rate after radical surgery was $1.3 \%$ in a multicenter study of 1412 cases. Aydin et al. [3] conducted a study in which they performed radical surgery in 92 patients and conservative surgery in 129 patients and reported the recurrence rates as $3.2 \%$ and $24 \%$, respectively.

Another study reported a recurrence rate of $7.9 \%$ in patients who underwent radical surgery during a 10-year followup [11]. Based on these results, it can be stated that radical surgical methods that are performed without opening the cysts can decrease the recurrence risk but do not eliminate it.

In our study, there were no recurrences in patients who underwent radical surgery; on the other hand, 14 recurrence cases were detected among patients who underwent conservative surgery. There was no statistically significant effect of the surgical method on the recurrence rate. Nevertheless, it is expected that radical surgery has a statistically significantly lower recurrence rate. However, due to the small number of patients who underwent radical surgery, it was difficult to interpret this result. 
In our clinic, conservative interventions have been implemented for a longer period of time and in a more standardized manner. Considering that conservative interventions Table 3. Distribution of the features of the cyst between the groups. Variable Recurrence (n(\%))

\begin{tabular}{|c|c|c|c|}
\hline & & Yes $(n=14)$ & No $(n=142)$ \\
\hline Age (year) & & $44.00 \pm 15.2$ & $39.94 \pm 17.5$ \\
\hline \multirow[t]{6}{*}{ Localization } & Liver right lobe & $9(64.28)$ & $78(54.92)$ \\
\hline & Liver left lobe & $1(7.14)$ & $27(19.01)$ \\
\hline & Liver right + left & $1(7.14)$ & $18(12.67)$ \\
\hline & lobe & & \\
\hline & Liver + abdomen & $2(14.28)$ & $13(9.15)$ \\
\hline & Abdomen & $1(7.14)$ & $6(4.22)$ \\
\hline Number of cysts & & $1.43 \pm 0.93$ & $2.54 \pm 8.49$ \\
\hline Cyst diameter $(\mathrm{cm})$ & & $10.93 \pm 2.73$ & $11.63 \pm 4.9$ \\
\hline \multirow[t]{5}{*}{ Gharbi grade } & Type 1 & 0 & 0 \\
\hline & Type 2 & $1(7.14)$ & $11(7.74)$ \\
\hline & Type 3 & $9(64.28)$ & $106(74.64$ \\
\hline & Type 4 & $4(28.57)$ & $23(16.19)$ \\
\hline & Type 5 & 0 & $2(1.40)$ \\
\hline \multirow[t]{2}{*}{ Preoperative ERCP } & Yes & $1(7.14)$ & $15(10.56)$ \\
\hline & No & $13(92.85)$ & $127(89.44$ \\
\hline \multirow[t]{10}{*}{ Surgical technique } & Omentoplasty & 0 & $2(1.40)$ \\
\hline & Capitonnage & 0 & $2(1.40)$ \\
\hline & Tube drainage & $3(21.42)$ & $1611.26)$ \\
\hline & Omentoplasty+ & & \\
\hline & tube drainage & $10(71.42)$ & $101(71.12$ \\
\hline & Capitonnage+ & & \\
\hline & tube drainage & $1(7.14)$ & $4(2.81)$ \\
\hline & Splenectomy & 0 & $5(3.52)$ \\
\hline & Pericystectomy & 0 & $11(7.74)$ \\
\hline & Resection & 0 & $1(0.70)$ \\
\hline \multirow[t]{3}{*}{ Cyst contents } & Rock water & $11(78.57)$ & $88(61.97)$ \\
\hline & Purulent & $2(14.28)$ & $28(19.71)$ \\
\hline & Bile & $1(7.14)$ & $26(18.30)$ \\
\hline \multirow[t]{2}{*}{ Biliary tract subsidiary } & Yes & $1(7.14)$ & $33(23.24)$ \\
\hline & No & $13(92.85)$ & $109(76.76$ \\
\hline \multicolumn{4}{|l|}{ Treatment of biliary tract } \\
\hline \multirow[t]{4}{*}{ subsidiary } & Primary suture & $1(7.14)$ & $25(17.61)$ \\
\hline & T-tube & 0 & $3(2.11)$ \\
\hline & Choledochoduode & & \\
\hline & nostomy & 0 & $5(3.52)$ \\
\hline \multicolumn{4}{|l|}{ Postoperative } \\
\hline \multirow[t]{4}{*}{ complications } & Wound infection & $1(7.14)$ & $7(4.92)$ \\
\hline & Biliary fistula & $1(7.14)$ & $8(5.63)$ \\
\hline & Cholangitis & 0 & $2(1.40)$ \\
\hline & Biloma & 0 & $3(2.11)$ \\
\hline
\end{tabular}

Use of medical treatment

0.563

$\begin{array}{lll}\text { Preoperative } & 14(100) & 115(80) \\ \text { Postoperative } & 14(100) & 125(88)\end{array}$

are much common and radical surgical interventions are rarely performed, a recurrence rate of $8.9 \%$ is notably low for our clinic. Moreover, the reported rates have been almost $20 \%$ in the majority of the studies.

There is a lack of sufficient studies in the literature analyzing the relationship between the content of the cyst and the recurrence rate. A study comprising 63 cases reported that $3 \%$ of recurrence cases had bile duct involvement, and the relationship between bile duct involvement and recurrence was statistically non-significant [12]. In our study, $7 \%$ of recurrence cases had bile duct involvement, but the relationship was not statistically significant.

Postoperative recurrence rate is parallel to the length of follow-up. Studies have reported that the recurrence rate after 1 year of surgery was $2.3 \%$ and $9.1 \%$ after 10 years. Therefore, an extended length of follow-up is recommended. Hydatid cyst disease that has recurred generally exhibits its symptoms 3-4 years after surgery $[12,18,19]$. That is why it is recommended to perform USG once a year and a CT scan biannually for 5 years after surgery [11].

There is no study in the literature regarding the relationship between preoperative ERCP and recurrence. In our study also, we did not determine any significant relationship between preoperative ERCP and recurrence rate. There was one patient with recurrence, and a total of 16 patients had preoperative ERCP. These numbers are inadequate in this regard, which could be the reason for this result. We believe that prospective studies with larger sample sizes are necessary in this area.

In conclusion, hydatid cyst is a benign disease and treatment choices for this disease should be made accordingly. We consider that in experienced clinics, the choice of treatment should be conservative and radical interventions should be limited to appropriate cases. Prevention of contamination during surgery and meticulousness in cavity management increase the value of these surgical interventions. Studies that are prospectively planned and involving larger patient groups are needed for determining the factors affecting recurrence after surgery of the liver hydatid cyst.

\section{References}

1.Eckert J, Deplazes P. Biological, epidemiological, and clinical aspects of echinococcosis, a zoonosis of increasing concern. Clin Microbiol Rev. 2004; 17: 107-35.

2. Torgerson PR, Williams DH, Abo-Shehada MN. Modelling the prevalence of Echinococcus and Taenia species in small ruminants of differentages in northern Jordan. Vet Parasitol. 1998;79: 35-51.

3.Aydin U, Yazici P, Onen Z, Özsoy M, Zeytunlu M, Kılıç M, et al. The optimal treatment of hydatid cyst of the liver: radical surgery with a significant reduced risk of recurrence. Turk J Gastroenterol. 2008;19: 339

4. Secchi MA, Pettinari R, Mercapide C, Bracco R, Castilla C, Cassone E, et al. Surgical management of liver hydatidosis: a multicentreseries of 1412 patients. Liver Int. 2010;30:85-93.

5.Amir-Jahed AK, Fardin R, Farzad A, Bakshandeh K. Clinical echinococcosis. Ann Surg. 1975;182: 541-6.

6. Gharbi HA, Hassine W, Brauner MW, Dupuch K. Ultrasound examination of the hydatic liver. Radiology. 1981;139:459- 6.

7.Kapan M, Kapan S, Göksoy E, Perek S, Kol E. Postoperative recurrence in hepatic hydatid disease. J Gastrointest Surg. 2006;10:734-9.

8. Sielaff TD, Taylor B, Langer B. Recurrence of hydatid disease. World J Surg. 2001;25:83-6.

9. Goksoy E, Saklak M, Saribeyoglu K, Schumpelick V. Surgery for Echinococcus cysts in the liver. Chirurg. 2008;79:729-37.

0.357 10. Sayek I, Tirnaksiz MB, Dogan R. Cystic hydatid disease: current trends in diagnosis and management. Surg Today. 2004;34:987-96. 
11. El Malki HO, El Mejdoubi Y, Souadka A, Zakiri B, Mohsine R, Ifrine $\mathrm{L}$, et al. Does primary surgical management of liver hydatid cys tinfluence recurrence? J Gastrointest Surg. 2010;14:1121-7.

12. Bülbüller N, Ilhan YS, Kirkil C, Yeniçerioğlu A, Ayten R, Cetinkaya Z. The results of surgical treatment for hepatic hydatidcysts in an endemic area. Turk J Gastroenterol. 2006;17:273-8.

13. Wani RA, Malik AA, Chowdri NA, Wani KA, Naqash SH. Primary extrahepatic abdominal hydatidosis. Int J Surg. 2005;3:125-7.

14. Guide lines for treatment of cystic and alveolar echinococcosis in humans. WHO Informal Working Group on Echinococcosis. Bull World Health Organ. 1996;74:231-42.

15. Arif SH, Shams-Ul-Bari, Wani NA, Showkat AZ, Wani MA, Tabassum $\mathrm{R}$, et al. Albendazole as an adjuvant to the standard surgical management of hydatid cyst liver. Int J Surg. 2008;6:448-51.

16. Besim H, Karayalçin K, Hamamci O, Güngör C, Korkmaz A. Scolicidal agents in hydatid cyst surgery. HPB Surg. 1998;10:347-51.

17. Yilmaz E, Gökok N. Hydatid disease of the liver: current surgical management. Br J Clin Pract. 1990;44:612-5.

18. Safioleas MC, Misiakos EP, Kouvaraki M, Stamatakos MK, Manti CP, Felekouras ES. Hydatid disease of the liver: a continuing surgical problem. Arch Surg. 2006;141:1101-8.

19. Agaoglu N, Türkyilmaz S, Arslan MK. Surgical treatment of hydatid cysts of the liver. Br J Surg. 2003;90:1536-41. 